\title{
STATUS OF PANGRE JHALAS WETLAND, MORANG DISTRICT, NEPAL
}

\author{
Puspa Lal Pokhrel, PhD (Wetlands) \\ Associate Professor of Geography Education, Central Department of Education \\ Tribhuvan University, Kirtipur, Kathmandu
}

Article DOI: https://doi.org/10.36713/epra6064

\begin{abstract}
Pangre Jhalas is a small riparian wetlands formed after the damming of a perennial river the Bakraha in a process of river training in the Morang district of the Eastern Nepal. It is one of the neglected wetlands in view of management but important asset of local livelihoods of indigenous communities and others. The author conducted socio-ecological assessment of this wetlands to explore the physical status and resource use condition of this wetlands by applying direct observation and household survey $(\mathrm{N}=45)$ using questionnaire and focus group discussion. Pangre Jhalas is a degrading wetlands with decreased water discharge and higher turbidity in comparison with water quality condition before 2005. The Dhimal are the indigenous major communities living at the shoreline of wetlands. Pangre Jhalas though small is the full of floral and faunal diversities. Dhimal communities rely of these resources for their subsistence livelihoods. Among the resources available, fish and Ghungi are the major products of wetlands, and absolute majority of $\mathrm{HHs}$ prefer it as consumptive resources, whereas crab as the least preferred. Only 31 percent of HHs use wetlands resources daily, and the intensity of resource use is higher in rainy season. The resource availability has been drastically declined over the years due to many mal practices such as over harvest by using unfriendly tools and traps.
\end{abstract}

KEY WORDS: Status of wetlands; diversity; flora; fauna

\section{BACKGROUND}

Nepal's National Wetlands Policy (2012) defines wetlands ' as "perennial water bodies that originate from underground sources of water or rainfall. It means swampy areas with flowing or stagnant fresh or salt water that is natural or manmade, or permanent or temporary. Wetlands also mean marshy lands, riverine floodplains, lakes, ponds, water storage areas and agricultural lands". Wetlands in Nepali colloquial is 'Simsar' derived from the union of 'Sim' (Persian word 'Sih' stands for low grade land), and ' $S a r$ ' (Sanskrit, meaning for 'water'); thus Simsar often interpreted as the land with water. However, Simsar has over fifty illustrative meaning in the world (WWF 2008) but over twelve in Nepal (Bhandari, 2009).All the wetlands are dynamic systems undergoing natural change and subjected to anthropogenic actions, and the temporary landscape features. It is understood that wetlands is one of the key components of sustainable development but very important to livelihoods of rural communities. In Nepal, wetland resources play pivotal roles for the ethnic communities particularly for subsistence livelihoods. Over, 21 ethnic communities are reported as wetlands dependent ones (IUCN 1998, 2004), some communities representing the most marginalized and poorest but furnished with indigenous knowledge to protect and conserve wetlands system in Nepal from the many years ${ }^{1}$ (Lamsal, Panta,Kumar \&Atreya 2015). In addition, wetlands ecosystem regulate environment, support ecosystem, mitigate climate change impacts, and provide multipurpose benefits such as cultural, education, recreational and other many direct or provisional (MEA 2005; Ramsar 2010,Wetlands International 2018; ILEC 2018, AWS 2018). .

\footnotetext{
1 In Nepal, the indigenous communities such as Dhimal, Satar, Rajbangsi, Meche, Godi and Musahar were nomadic people at the beginning to till the fifteen century. They used to hunt and gather wild animals, fruits, wild roots and bulbs to maintain their daily life. When there was paucity of land to hunt and collect fruits, they begun to first settle around the dry lands of most important wetlands area of Jhapa and Morang districts. Then they have been involving in farming and fishing. They extracted wetlands resources including fishes as the key resource for their immediate use. In addition, they also used to extract shell; Ghungi; crab, and mat weaving raw materials special from the Cattail and Toad Rush for additional source of income (Pokhrel 2017, WWT 2009).
} 
Pangre Jhalas is one of the peculiar types of wetlands in the Morang district of Province 1 of Nepal with the Dhimal, one of the indigenous communities, living around it, applying their traditional skills and tools to protect and conserve wetlands resources. Their traditional practices of resource management are believed to retain wetlands features, though also believed modify in spatial ways. The present paper examines the status of Pangre Jhalas specially the state of biodiversity and resource use values that Dhimal successfully managed to retain species richness and cultural values in the past and now.

\section{METHODOLOGY}

Researcher conducted household survey $(\mathrm{N}=45)$ in January 2017 using structured and nonstructured questionnaire for the primary data followed by Focus Group Discussion (FGD) among elders of the Dhimal community also associated other groups like Brahmin and Chhetri. Transect walk and direct observation, inventory, and resource assessment were done by applying Wetlands Inventory, Assessment and Monitoring Tool (MoFSC 2010). A simple GIS tool applied for area mapping the Pangre Jhalas.

\section{Description of research site}

The Pangre Jhalas is located in Pathari Shanishchare Municapility-5 previously the Hasandaha Village Development Committee in the Morang district of Province 1, Nepal along the west bank of the Bakraha River. It is elongated north to south, and extended between $26^{\circ} 35^{\prime} \mathrm{N}$ and $87^{\circ} 36^{\prime} \mathrm{E}$ at the elevation between 94 masl in south to 98 masl in north (Figure 1). The area of the wetlands is about 22 hectare $\left(0.22 \mathrm{~km}^{2}\right)$ surrounded by the cultivated land in west and the Bakraha River in east. The running length of wetlands is 2023.68 meters, whereas width varies measuring $64 \mathrm{~m}$ in north, $552 \mathrm{~m}$ in middle and $92 \mathrm{~m}$ in south. An average width is 236 meters. Average depth is $1.5 \mathrm{~m}$. There are 12 wetlands in Morang District.

Pangre Jhalas is a small eutrophic shallow oxbow wetlands surrounded by marshes; meadows; paddy field; and tropical reeds (Saccharum spontaneum); thatch grass; rushes, and cattail (Typha elephantine) at shoreline, and degraded pastureland in south. Many floating aquatic vegetation in core area are visible sufficiently. It is drained by the Bakraha Khola, and subjected to intense flooding in monsoon season.

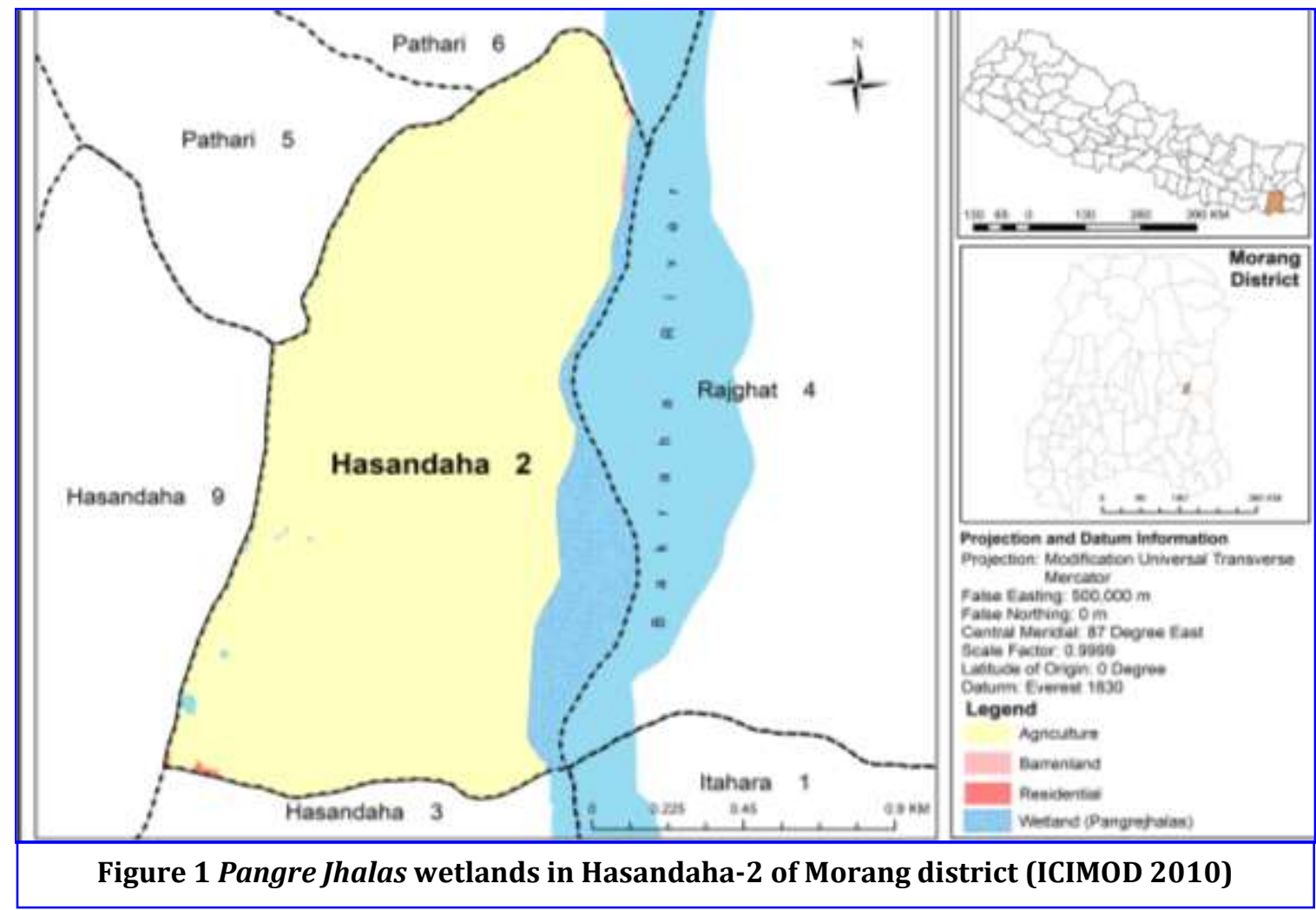

The area receives tropical monsoon climate, hotter summer and warmer winter. An average annual rainfall ranges from $200-250 \mathrm{~cm}$ with about 90 percent of it occurs from the mid-June to
September during monsoon period. A small amount of rainfall in winter often evidenced as the result of south westerly winds from the Arabian Sea. An 
average temperature is $24^{0} \mathrm{C}$ with maximum and minimum of $40^{\circ} \mathrm{C}$ and $10^{\circ} \mathrm{C}$ respectively.

\section{RESULTS AND DISCUSSION Origin and status of wetlands}

Pangre Jhalas is a newly formed wetland from the bow shaped bend in the former channel of Bakraha River. In earlier, it was a floodplain which was detached from main river course when embankment was constructed in the west border of river in 1991 (2048 B.S.), and Pangre Jhalas received the attention from public general as a separate wetlands identity. An associated wetlands to Pangre Jhalas is Bakraha wetland which is about 60 hectares $\left(0.6 \mathrm{~km}^{2}\right)$ with the frequent water discharge from Bakraha River in both the wetlands during monsoon.
Pangre Jhalas wetland was large and wide with an area of more than 30 hectare till 1990s, and a branch (Bhangalo) of Bakraha River used to pass across the place which presents wetlands is present. After the construction of embankment, the river branch was blocked, and entire bock-part emerged out as persistent marshy land, currently the Pangre Jhalas. Figure 2 is a brief illustration that local people perceive and assess the wetlands health and resource use value before and after 2005. Local and indigenous communities claim that wetlands health is degrading and resource use in term of availability is declining when compared in a spatial scale. Once, the good water quality as potable is no more useable as drinking water.

\begin{tabular}{|c|c|c|c|}
\hline SN & Physical Feature & Before 2005 & After 2005 \\
\hline 1 & Area & & 1 \\
\hline 2 & Length & & 1 \\
\hline 3 & Breadth & & \\
\hline 4 & River bed & & \\
\hline 5 & Water quality & Potable & Non-potable \\
\hline 6 & Turbidity & Low & High \\
\hline 7 & Fauna & & \\
\hline 8 & Flora & & \\
\hline \multirow[t]{2}{*}{9} & General use value & & \\
\hline & No change & Declining & Increasing \\
\hline
\end{tabular}

Figure 2 Trend of change in physical structue of the Pangre

Jhalas at spatial scale (Source: Assessment Study 2017)

\section{Wetlands flora and fauna}

Pangre Jhalas holds 12 species of fishes, and fish stock has been declining (Table 1). Local people claim that fish stock declined due to over fishing and harmful fishing practices combined with infrastructure development such as road and embankment. The local fishes namely Soul (Channa marulius) and Singi fishes (Heteropeustes fossilis) which used to occur commonly before are no more observed these days.

\begin{tabular}{|c|c|c|c|c|c|c|}
\hline \multicolumn{7}{|c|}{ Table 1: Fish diversity in Pangre Jhalas Wetland } \\
\hline \multirow{2}{*}{ SN } & \multicolumn{2}{|r|}{ Fish Diversity } & \multicolumn{2}{|c|}{ Use Value $(\mathrm{N}=45)$} & \multicolumn{2}{|c|}{ Resource Availability } \\
\hline & Local Name & Type of fishes & HHs No. & $\%$ HHS & Before 2005 & After 2005 \\
\hline 1 & Bam & Anguilla bengalensis & 45 & 100 & & $\checkmark$ \\
\hline 2 & Hile & Channa stewarti & 44 & 97.78 & & 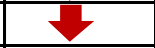 \\
\hline 3 & Mangri & Clarias batrachus & 43 & 95.56 & & 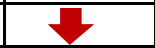 \\
\hline 4 & Sidra & (Punitus panctatus) & 44 & 97.78 & & \\
\hline 5 & Gaichi & (Macrognathus aculeatus) & 36 & 80.00 & & $y$ \\
\hline 6 & Jhinge & (Palaemon malcolumsoni) & 44 & 97.78 & & \\
\hline 7 & Paiya & (Progastus) & 33 & 73.33 & & $\zeta$ \\
\hline 8 & Deri & (Esomus dendricus) & 43 & 95.56 & & $z$ \\
\hline 9 & Pothi & (Puntius sophore) & 43 & 95.56 & & $\zeta$ \\
\hline 10 & Buwali & (Wallago attu) & 14 & 31.11 & & \\
\hline 11 & Garai & (Channa puntatus) & 10 & 22.22 & $\Gamma$ & \\
\hline 12 & AndhaBam & (Amphipnous cuchia) & 5 & 11.11 & $\zeta$ & \\
\hline 13 & Singhee & Heteropeustes fossilis (Disappear) & $E$ & & & \\
\hline 14 & Soul & Channa marulius (Disappear) & & & & \\
\hline
\end{tabular}


Pangre Jhalas commonly featured with marshes remains wet throughout year, and is the habitat for reeds and sedges, and breeding/staging areas for resident birds. In addition, it is abundant with aquatic angiosperms such as cattail (Typha angustifolia); water hyacinth (Eichhornia crassipes); sweet flag (Acorus calamus); species of reeds and sedges; pani unyou (Hydrilla verticillata); Karmi saag (Ipomoea aquatic); Banmara (Chromolaena odorata); Niguro (Dryopteris cochleata); Kans (Saccharum spontaneum). The area is reported to hold over 12 species of floating hydrophytes; they provide a nesting habitat for birds such as the pheasant- tailed Jacana; Bronze winged Jacana; Purple Moorhen, and Pintails () (Sankhala, 1990; IUCN 2004), and food for fish and habitat for large numbers of invertebrates, especially crustaceans. A number of algae species such as Chara, Nitella. and Spirogyra. Emergent plants share common hydrophytic characters and are highly sensitive to seasonal fluctuations in the water level, which generally occupies the water margin of the wetlands.

Occupation

\begin{tabular}{|c|c|c|c|c|}
\hline \multirow{2}{*}{ Occupation } & \multicolumn{2}{|c|}{$\mathrm{HHs}(\mathrm{N}=45)$} & \multirow{2}{*}{$\begin{array}{l}\text { Land holding } \\
\text { (Bigaha) }\end{array}$} & \multirow{2}{*}{ Key income source } \\
\hline & No & $\%$ & & \\
\hline Waging, fishing and mat weaving from cattail & 10 & 22 & Landless & Fish and mat selling \\
\hline Waging and fishing & 5 & 11 & Below0-5-0 & Fish selling \\
\hline Agriculture and alcohol production & 6 & 13 & $0-6-0$ to $0-10-0$ & Alcohol selling \\
\hline Agriculture and foreign employment & 8 & 18 & $1-0-0$ to $1-5-0$ & Remittance \\
\hline Agriculture and teaching & 1 & 2 & $1-5-0$ to $2-0-0$ & Teaching \\
\hline Agriculture and fishing & 16 & 36 & $2-0-0$ to $4-0-0$ & Agriculture \\
\hline Total & 45 & 100 & & \\
\hline
\end{tabular}

Table 4 Key occupation, landholding and income source of Dhimal communities. Note: 1 Bigaha = 0.6773 Hectare (Source: Field survey, January, 2017).

Table 4 illustrates on occupational activities of Dhimal communities. More than one third households are fully depended on wetland for surviving their livelihood. Among them majority of households are engaged in labour wage and mat weaving from cattail and eleven percent households are engaged in waging and fishing. On the other hand, landless households are engaged in wage work, fishing and mat weaving activities. Those households, who have less than 0-5-0 bighas agricultural land, are involved in waging and fishing. One third households collects wetland products to sell in the market for money and more than two third of households collects wetland products for their domestic use. In the past, fishing was an important economic activity in this surrounding area. At present fishing activities has declined due to degrading of wetlands. According to local people, in the past the Dhimal and other indigenous community of make livelihood out of the wetlands resources such as fish, crab, shell snail, vegetable, and reeds. While they have been dwelling in the wetlands vicinity, directly use its water for drinking purposes, swimming, and clothing and also for irrigating their agricultural lands

\section{Resource use of wetlands}

Dhimal understand wetland as the resource basket for cattail; toad rush; fish and other resources. For them it is the place where they could access and harvest resources, but cannot grow paddy due to difficulties to act for farm activities like ploughing and weeding. Table 2 shows households that use different wetlands fauna as resources as key element of their livelihoods. Fish; Shell; Ghungi; crab; wetlands birds and some vegetables like as water cress (Kanchi Saag), swamp cabbage (Karmi Saag), and sweet flag are key products that people harvests from the wetlands. The majority of Dhimal people are depended on wetland for nutrients. Wetland resources are a main source of nutrient because these products are unpaid commodities easily available especially in the rainy season. Among these, fish and Ghungi are the major products of wetlands, and absolute majority of $\mathrm{HHs}$ prefer it as key consumptive resources, whereas crab as the least preferred (Table 2).

The periodical use of the wetlands resources by the communities drastically varies, which may be due to abundance of resources in particular period of a year. For example, only 31 percent of HHs use wetlands resources daily followed by higher use of resources during rainy season. In winter, very nominal use of resources is noted (Table 3). The communities responded that these resource availability is drastically declined over the years due to several wetlands activities such as over harvest of the resources by using unfriendly tools and traps.

Dhimal households have small number of livestock population. The Pangre Jhalas and Bakraha wetlands are favorable grazing site for livestock of Hasandaha settlement. This study observed that the IPangre Jhalas is also a grazing site for the livestock of other adjoining settlements including west Urlabari municipality and North West Ratuwamai 
municipality, previously the Itahara and Rajghat

village development committees respectively.

\begin{tabular}{|lrrrr}
\hline \multicolumn{5}{l}{ User/non user HHs (N=45) } \\
\hline Key fauna preferred & User & \multicolumn{2}{l}{ None user } & \% users \\
\hline Fish & 45 & 0 & 100 \\
\hline Shell & 36 & 9 & 86.66 \\
\hline Ghungi & 45 & 0 & 100 \\
\hline Crab & 44 & 1 & 2.27 \\
\hline Wetland bird & 35 & 10 & 22.22 \\
\hline
\end{tabular}

Table 2 Use and non-use preference of wetlands fauna as resources (Source: Field survey, January, 2017)

\begin{tabular}{|l|c|c|}
\hline \multicolumn{1}{|c|}{ Periods } & $\begin{array}{c}\text { Frequency } \\
(\mathrm{HHs})\end{array}$ & Percentage \\
\hline Daily & 14 & 31 \\
\hline Weekly & 6 & 13 \\
\hline Twice a week & 2 & 4 \\
\hline Monthly & 8 & 18 \\
\hline Winter use (weekly) & 1 & 2 \\
\hline Rainy season & 14 & 31 \\
\hline Total & 45 & $\mathbf{1 0 0}$ \\
\hline $\begin{array}{l}\text { Table 3 Use of fish resource as diem (Source: } \\
\text { Field survey, January, 2017 }\end{array}$ \\
\hline
\end{tabular}

\section{MajorThreats of Wetlands}

Anthropogenic impacts on wetlands are spreading in most parts of the Eastern Tarai and becoming more intense in quantity and quality due to increased human population and their activities. The high rate of deforestation in surrounding catchment area of Churia Region and Bhabar Tract and use of pesticides and fertilizers have Spurred the spread of invasive species. In eastern Tarai, there are numerous threats to standing fresh water wetlands ecosystems. These include phenomena which occur naturally due to highly dynamic processes linked to geographical characters such as geomorphology and climatic conditions, in particular flooding, erosion, transportation, sedimentation and other hydrological changes. Diversion of standing wetlands water for use in irrigation, fishing, and invasion of plant and introduction of exotic animal species and contamination from the toxics, agro-chemicals and nutrients from cultivated land, sewage, and village market runoff are common today that significantly threatens wetlands ecosystems. These threats are also common to Pangre Jhalas (Figure 2) including the overfishing the priority threats topping the list.

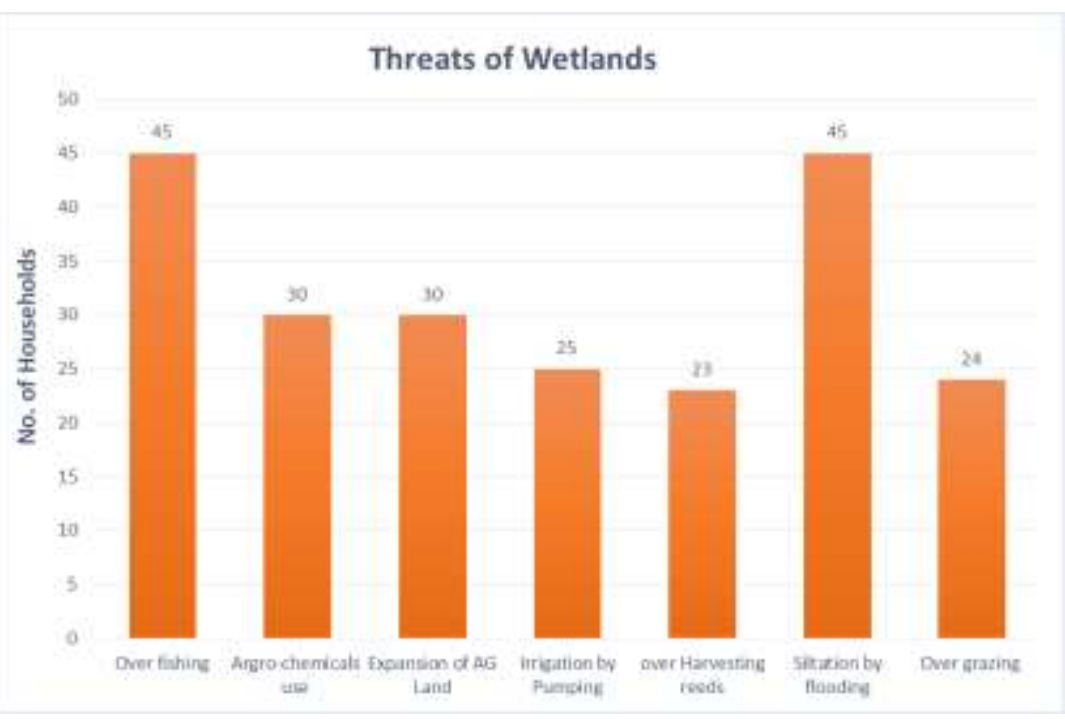


In addition to above, some key observations during threat assessment in Pangre Jhalas are:

Sedimentation: Bakraha river carries huge amount of silt and sand during floods, and these elements are annually discharged into wetlands. The higher sediment load is mainly associated with flood as well as administration of soil for agriculture use.

Mutation of wetland in agricultural land: Pangre Jhalas wetlands has been draining out often by water pumps to provide irrigation since mid of 1990s. As a result, water volume is maintained at lower level some time even not sufficient for aquatic life.

Overgrazing: Open grazing is common in the rural areas of eastern Terai. There still consists a traditional socio cultural and agricultural practice. Grass land areas are being limited in Teri due to urbanization process, development of new small market centre's and rapid population growth. Remaining limited grasslands around the wetlands have high pressured of heavy grazing. In the Himalayan region, a pasture grazing is a seasonal threat (IUCN 2004). But those marshes and oxbow lakes, which are located in Morang and Jhapa are continuously facing threats all over the year. Over grazing activities is common phenomena surrounding wetland environment of Morang and Jhapa which leads to disturbance in bird habitat through the ruination of the nests of ground dwelling species like as nest of Hutitaun and Simkukhura.

Weak land registration policy: Most of the wetlands were not registered before 1980s. They were possession under the government. They are called locally Ailani Jagga (barren land or open land not registered yet in a personal) by the government. When population increased rapidly at the same time urbanization process is also increased in the same ratio, the wetlands are registered by land exploiters in personal name with the help of land revenue officers. First of all, land exploiter filled the wetland to transfer into the agricultural land then register as personal assets. The weak registration policy is a cause of wetlands degradation.

Lack of protection law to conserve private wetlands: There is no conservation law for private wetland. The owner can easily modify his wetland according to his interest. They are unknown about importance of wetlands. Therefore private wetland is diminishing rapidly and converted as an agricultural and residential land.

Draining method has losses of feeding and breeding sites of aquatic and faunal diversity. The general view of the users of the wetlands is that; it must be protected. Especially the older users of Dhimals are convinced that the environment of the surrounding area has deteriorated and that steps have to be taken to protect it from the further damage

\section{CONCLUSION}

Pangre Jhalas is a newly formed oxbow type of wetlands. In the beginning the wetlands had huge area. The area was rich in faunal and floral biodiversity. The water was potable, now it is being polluted. In the present days, due to over and harmful fishing practices fish stocked have declined rapidly. Harmful fishing methods diminished the total faunal population by mass killing. Two species of fishes are no more in scene. Thirty three percent of households are fully dependent on wetlands resources for their subsistence. The Dhimal are one of the poorer local and indigenous communities rely much on wetland for their supplementary nutrients they obtain chiefly from vegetable, fishes and Ghungi. But these resources are declined due to harmful fishing technique and over harvesting activities. The major threats of Pangre Jhalas are sedimentation from floods; wetlands conversion for agriculture land; over-grazing; weak law enforcement, and poor understanding of wetlands dynamics among local communities.

\section{Acknowledgement}

I greatly acknowledge to Professor Dr. Narendra Khanal, Professor Dr. Bhim Prasad Subedi and Shailendra Pokharal for their valuable and critical inputs for the preparation of this paper.

\section{REFERENCES}

1. Asian Wetland Symposium (2018). Wetlands for Sustainable Life. 8th Asian Wetland Symposium 2017 Proceedings. Tokyo, Japan.

2. Bhandari B.B.(2009). Wise Use of Wetlands in Nepal. BANKO JANAKARI. A Journal of Forestry Information for Nepal. Department of Forest Research and Survey (DFRC). Ministry of Forests and Soil Conservation, Government of Nepal: pp 10-17.

3. International Lake Environment Committee (2018). Managing Lakes and Their Basins for Sustainable Use. Lake Basin Management Initiative (LBMI). Japan

4. IUCN (2004).A Review of the Status and Threats to Wetlands in Nepal. IUCN, Wetlands and Water Resource Programme, Blue Series. IUCN Nepal Country Office

5. IUCN,( 1996). Pan AFRICAN symposium on Sustainable Use of Natural Resources and Community Participation. Harare, Zimbambwe, June 24-27, 1996.

6. Lamsal, P., K. P. Pant, L. Kumar, and K. Atreya. (2015). Sustainable livelihoods through conservation of wetland resources: a case of economic benefits from Ghodaghodi Lake, western Nepal. Ecology and Society 20(1): 10.

7. Millennium Ecosystem Assessment (2005). Ecosystems and human well-being: wetlands and water synthesis. Washington DC: World Resources Institute. 
8. Pokhrel, Puspa Lal (2017), Wetlands of Jhapa and Morang Districts: A Study of Status, Dynamics, Utilization and People's Perception. Kathmandu: Unpublished Doctoral Disse|rtation. Tribhuvan University.

9. Ramsar Convention Secretariat (2010). Wise use of wetlands: Concepts and approaches for the wise use of wetlands. Ramsar handbooks for the wise use of wetlands, 4th edition, vol. 1. Ramsar Convention Secretariat, Gland, Switzerland.

10. Sah, J.P.(1997). Koshi Tappu Wetlands: Nepal's Ramsar Site.The International Union for Conservation of Nature and Natural Resources. IUCN Country office, Kathmandu, Nepal

11. Shankhala, K.(1990). Gardens of God: The water bird sanctuary at Bharatpur. Vikas Publishing House Pvt.Ltd.

12. Wetlands International (2018). Wetlands Solutions for the People and Nature. Wageningen, Netherlands.

13. Wildfowl and Wetlands Trust (2009). Koshi Wetlands for Life. Community Wetlands Programme, University of Stirling, Slimbridge, $U K$.

14. WWF (2004). The Economic Values of the Worlds' Wetlands. Kirsten Schuyt and Luke Brander (ed), Gland, Amsterdam. 